anales de psicología / annals of psychology

2020, vol. 36, $\mathrm{n}^{\circ} 3$ (october), 400-407

https://doi.org/10.6018/analesps.428631
(C) Copyright 2020: Editum. Servicio de Publicaciones de la Universidad de Murcia. Murcia (Spain) ISSN print edition: 0212-9728. ISSN online edition (http://revistas um es/analesps): 1695-2294

Online edition License Creative Commons 4.0: BY-SA

\title{
Needs analysis for the personal, social, and psychological adjustment of adolescents at risk of delinquency and juvenile offenders
}

\author{
1 Universidad Santo Tomás (Colombia) \\ 2 Universidad de Santiago de Compostela (Spain) \\ 3 Universidad de Vigo (Spain)
}

Erika Mayorga ${ }^{1}$, Mercedes Novo $^{2 *}$, Francisca Fariña ${ }^{3}$, and Dolores Seijo ${ }^{2}$

\begin{abstract}
Título: Estudio de las necesidades en el ajuste personal, social y psicológico en adolescentes en riesgo de delincuencia e infractores.

Resumen: La literatura ha encontrado que las necesidades nocriminogénicas también son un factor de riesgo de delincuencia juvenil y, por tanto, han de ser objeto de intervención. Se diseñó un estudio de campo con el objetivo de conocer si el ajuste individual, social y psicológico (necesidades no-criminogénicas) difieren entre menores infractores, menores de protección y normalizados. Para ello se evaluó a 450 adolescentes (150 menores de reforma, 150 de protección y 150 normalizados) en el ajuste individual, social y psicológico. Los resultados mostraron un efecto significativo en el ajuste individual, social y psicológico para el factor población. Sucintamente, los menores de protección y reforma manifestaron un mayor desajuste individual en los niveles personal y familiar que los normalizados, y, adicionalmente, los de reforma a nivel social. Asimismo, los menores de protección e infractores exhibieron un mayor desajuste social consistente en más retraimiento social, ansiedad social/timidez y liderazgo que los normalizados, y los menores infractores un menor ajuste social en la consideración hacia los demás que los normalizados. En el ajuste psicológico, los menores de reforma y protección informaron de más sintomatología obsesivo-compulsiva, de sensibilidad interpersonal, depresiva, de hostilidad, de ansiedad-fóbica y psicótica que los normalizados, y los de protección más somática, ansiosa (generalizada) y paranoide que los normalizados. Se cuantificaron los déficits en estas dimensiones para estimar la magnitud de las necesidades. Se discuten las implicaciones teóricas de los resultados y para el diseño de programas de prevención de la delincuencia y
\end{abstract} de recaídas.

Palabras clave: Necesidades no-criminogénicas; Menores de reforma; Adolescentes de protección; Desajuste individual; Desajuste social; Desajuste psicológico.

\section{Introduction}

Several studies on delinquency have identified an array of factors related to delinquency such as risk factors that are variables predicting with a high probability antisocial and/or delinquent behaviour (Farrington, Gaffney, \& Ttofi, 2017); risk protective factors are variables predicting a low probability of delinquency among individuals at risk; interactive protective factors are variables buffering or cancelling the effects of delinquency risk factors; promotive factors are variables predicting a low probability of offending, and mixed risk and promotive factors that are variables either positively related to a low probability of delinquency, or negative related to a high probability of delinquency (Farrington, Ttofi, \& Piquero, 2016). These factors are mutually associated and underpin models of vulnerability and incompetence (Arce,

* Correspondence address [Dirección para correspondencia]: Mercedes Novo. Facultad de Psicología. Campus Vida, s/n. E-15782 Santiago de Compostela, A Coruña (Spain). E-mail: mercedes.novo@usc.es (Article received: 19-05-2020; revised: 25-05-2020; accepted: 12-06-2020)
Abstract: Literature has found that non-criminogenic needs also are a juvenile delinquency risk factor and, consequently, should be target of intervention. With the aim of knowing if individual, social and psychological adjustment differ between juvenile offenders and foster care adolescents with normal adolescents, a field study was designed. A total of 450 adolescents (150 juvenile offenders, 150 foster care adolescents, and 150 normal adolescents) were evaluated in individual, social and psychological adjustment. The results showed a significant effect in the individual, social and psychological adjustment for the population factor. Succinctly, juvenile offenders and foster care adolescents displayed a higher individual maladjustment in the personal and family level than normal adolescents, and, additionally, juvenile offenders in the social level. Likewise, juvenile offenders and foster care adolescents exhibited a higher social maladjustment consisting in more social withdrawal, social anxiety/shyness, and leadership than normal adolescents; and juvenile offenders revealed less consideration for others than normal adolescents. In psychological adjustment, juvenile offenders and foster care adolescents reported more obsessive-compulsive, interpersonal sensitivity, depression, hostile, phobic-anxiety, and psychotic symptomology than normal adolescent; and foster care adolescent more somatic, anxiety (generalized) and paranoid symptoms than normal adolescents. The deficits in these needs were quantified as to estimate the magnitude of the intervention. Theoretical and practical implications for intervention of the results are discussed.

Keywords: Non-criminogenic needs; Juvenile offenders; Foster care adolescents; Individual maladjustment; Social maladjustment; Psychological maladjustment.
Seijo, Fariña, \& Mohamed-Mohand, 2010; McGuire, 2000; Werner, 1986), as well as models of protective/promotion, and competence, in particular socio-cognitive competence (Arce, Fariña, \& Novo, 2014; Lösell, Kolip, \& Bender, 1992). In this association, individual, family, and sociocommunity variables act as a driving nexus, particularly in adolescence (Farrington et al., 2016; Loeber, Slot, \& Stouthamer-Loeber, 2008). In fact, evidence has been found to support the claim that high risk adolescents have a natural tendency towards social deviancy (accumulating more risk factors and incompetence from pre-adolescence to adolescence), whereas no-risk adolescents have a natural tendency towards social adjustment (increase protective and promotive factors during the transition from pre-adolescence to adolescence) (Arce et al., 2010). In terms of the family, good functioning of the family unit, parental monitoring (e.g., control, support), and family cohesion are predictors of a positive social adjustment in adolescence, whereas dysfunctional families with poor parental monitoring have been associated to antisocial and delinquent behaviour (Hoeve et al., 2009; Novo, Fariña, Seijo, Vázquez, \& Arce, 2019). Thus, the 
family constitutes a mixed risk and promotive factor. As for social adjustment, the community and neighbourhood factors constituted a risk factor (high risk delinquency community/neighbourhood), or protective factor (low risk delinquency community/neighbourhood) from antisocial and delinquent behaviour (mixed risk and promotive factor) (Fariña, Arce, \& Novo, 2008); and the association to deviant peer affiliations was strongly related to delinquency - risk factor- (Arce et al., 2011; Cutrín, Maneiro, Sobral, \& GómezFraguela, 2019). Likewise, school adjustment and academic achievement have been linked to protective factors of antisocial behaviour, whilst poor academic performance, school absenteeism and dropouts, rather than being conceived as a risk factor, school maladjustment should be understood as the outcome of personal, social, and family maladjustment - promotive factor- (Álvarez-García, Núñez, García, \& Barreiro-Collazo, 2018; Corrás et al., 2017). As for individual factors, the literature has associated internalizing symptomology, aggressive behaviour (Marshall, Arnold, RolonArroyo, \& Griffith, 2015; Smokowski et al., 2017), and psychological maladjustment to the risk of recidivism in delinquency (Basanta, Fariña, \& Arce, 2018), clinical morbidity and recidivism in delinquency (Wibbelink, Hoeve, Stams, \& Oort, 2017), and the influence of toxic cognitions (e.g., hostility, anger, delusions of persecution), as underlying mechanisms explaining violent behaviour (Novo et al., 2012), and recidivism in violent behaviour (Hutchings, Gannon, \& Gilchrist, 2010; Maruna, 2004). In relation to the intervention, these risk factors may remain static (unmodifiable) or dynamic and modifiable, and are thus the target of the intervention itself, that is, the needs to be intervened (Bonta \& Andrews, 2017). Dynamic factors have been defined in Bonta and Andrews' intervention as needs, but a distinction is made between criminogenic needs linked to criminal behaviour, and non-criminogenic needs, where changes in individual or circumstantial variables have no direct impact on the recidivism rate, underscoring the intervention should focus on criminogenic needs. Nevertheless, recidivism in delinquency is related to deficits in non-criminogenic needs such as psychological adjustment that explained $19.5 \%$ of the risk of recidivism in delinquency (Basanta et al., 2018), with externalizing disorders $(d=0.415$, explaining $4.1 \%$ of recidivism), comorbid -internalizing and externalizing- ( $d=$ 0.366, explaining 3.2\% of recidivism) (Wibbelink et al., 2017), and social skills (e.g., consideration for others; selfcontrol in social relations) explaining $21.6 \%$ of the risk of recidivism in delinquency (Basanta et al., 2018); thus, these factors were not the root cause of delinquency, but facilitated recidivism. Moreover, these estimates explaining recidivism were underestimated given that the measures of recidivism in Official Records fail to identify most real recidivism (Arce, Arias, Novo, \& Fariña, 2020). Hence, interventions must also target these needs.

Bearing in mind this context, the aim of the present study was twofold: to determine if individual, social, and psychological adjustment differ between juvenile offenders, adolescents in foster care (at risk), and normal adolescents; and if so, to quantify the global deterioration in individual, social, and psychological adjustment and in each of their dimensions among juvenile offenders, adolescents in foster care and normal adolescents (controls).

\section{Method}

\section{Participants}

The sample consisted of 450 Colombian adolescents from Bogotá or Tunja aged from 14 to 19 years $(M=16.07$ years; SEM $=0.21)$, 150 were juvenile offenders with an average 18.41 months $(S E M=0.80)$ detention in juvenile correctional centres; 150 were adolescents in foster care and wards of juvenile dependency courts with an mean stance period of 37.49 months $(S E M=3.09)$; and 150 normal adolescents. The sample were matched in gender, $\chi^{2}(2)=0.87$, $n s$, with 227 adolescents girls (72 offender, 80 foster care, and 75 normal adolescent girls), and 223 adolescent boys (78 offender, 70 foster care, and 75 normal adolescent boys).

Of the juvenile offenders, $80 \%$ were on remand for theft, $5.3 \%$ assault, $11.3 \%$ homicide, $2 \%$ sexual offences, and $1.3 \%$, illicit drug trafficking.

\section{Measurement instruments}

Participants completed an ad hoc sociodemographic questionnaire designed for this study to gather data on the participants' age, gender, academic status, criminal record, child court protection orders, and social status.

As for the assessment of social skills, participants completed the Bateria de Socialización BAS-3 [BAS-3 Socialization Inventory] (Silva \& Martorell, 1989). This scale, consisting of 75 items with a Yes or No response format, measures five dimensions of social skills: consideration for others $(\alpha=.82$, for the participants in this study); self-control in social relations $(\alpha=.78)$; social withdrawal $(\alpha=.81)$; social/shyness anxiety $(\alpha=.78)$; and leadership $(\alpha=.73)$.

In order to measure the individual adjustment, participants were administered the (Test Autoevaluativo Multifactorial de Ajuste Infantil (TAMAI) [Multifactorial Child Adjustment Self-evaluation Test] (Hernández, 2002), consisting of 115 items with a Yes or No response format evaluating personal $(\alpha=.85)$, social $(\alpha=.75)$ school $(\alpha=.86)$, and family $(\alpha=.75)$ maladjustment, and parental attitudes towards education $(\alpha=.75)$.

Psychological adjustment was measured using the Spanish version of the Brief Symptoms Inventory [BSI] (Aragón, Bragado, \& Carrasco, 2000), consisting of 53 items on a 5point Likert-type scale with responses ranging from Not at all (0) to Extremely (4), to evaluate 9 symptomatic dimensions: somatization $(\alpha=.96)$, obsessive-compulsive $(\alpha=.94)$, interpersonal sensitivity $(\alpha=.90)$, depression $(\alpha=.91)$, anxiety ( $\alpha=.93)$, hostility $(\alpha=.91)$, phobic-anxiety $(\alpha=.88)$, paranoid ideation $(\alpha=.93)$ and psychoticism $(\alpha=.91)$. Further- 
more, it comprises three global indices of distress: the Global Severity Index (GSI), the Positive Total Symptoms (PST), and the Positive Symptom Distress Index (PSDI).

\section{Design and procedure}

A field study was carried out with a quasi-experimental design for comparing the means between three subsamples of participants (juvenile offenders, adolescents in foster care, and normal adolescents). Design sensitivity analysis with the comparison of means between 3 groups, with 3 to 9 dependent variables (MANOVA) and a sample size of 450 subjects, found the probability of detecting $(1-\beta)$ significant differences $(\alpha<.05)$ for a medium effect size $\left(\mathrm{f}=.25 / \mathrm{f}^{2}=.065\right)$ ranged from $98 \%$ to $100 \%$.

The measures were obtained by trained and experienced researchers who ensured the correct administration and completion of all tests and questionnaires in the centres or schools corresponding to each adolescent. The data was collected in one session at each centre, with the exceptional of cases requiring two sessions owing fatigue. As the order of test administration could influence the measures analysed in this study, leading to a systematic measurement error i.e., adding an alternative explanation to the effect analysed (Arce, Fariña, \& Fraga, 2000), the order of test administration was counterbalanced (A-B-C; A-C-B, B-C-A, B-A-C, C$\mathrm{B}-\mathrm{A}, \mathrm{C}-\mathrm{A}-\mathrm{B})$. For the evaluation of the juvenile offenders, authorization was obtained from the courts and correctional centres, for adolescents in foster care authorization was obtained from the appropriate public authorities and care centres responsible for the adolescents; and for normal adolescents informed consent was obtained from parents or legal guardians. All of the adolescents freely volunteered to participate in the study. The time for completing the questionnaires and tests ranged from 30-40 minutes.

Data were processed according to Spanish Data Protection Law (Ley Orgánica 3/2018, de 5 de diciembre, de Protección de Datos Personales y Garantía de los Derechos Digitales, 2018).

\section{Data analysis}

For the comparison of means between groups in the factor population, MANOVAs were performed when warranted i.e., when the dependent variables formed a correlated theoretical construct. As an omnibus test in MANOVA, the Pillia-Bartlett's trace was used for its superior robustness to the violation of the homogeneous variance-covariance assumption, with the exception of groups differing in only one variable where Roy`s maximum root was most powerful (Ol- son, 1976). Post hoc test were performed with bonferroni correction $(1 / \mathrm{m})$. The effect size $\eta_{\mathrm{p}}{ }^{2}$ was calculated in the multivariate tests and Cohen's $d$ by the standardized mean difference. The magnitude of the effect sizes were interpreted using the Probability of Superiority of the Effect Size ((PS $\mathrm{ES}_{\text {; }}$ Monteiro, Vázquez, Seijo, \& Arce, 2018)) for $d$, and the explained variance for $\eta_{\mathrm{p}}{ }^{2}$. The PS $\mathrm{PS}$ expressed the percentage of effect sizes over the total that would exceed the observed. The BESD was used to quantify deficits in the sample populations (Redondo, Fariña, Seijo, Novo, \& Arce, 2019).

\section{Results}

\section{Individual adjustment}

The results of the MANOVA showed a significant multivariate effect in individual adjustment for the population factor (juvenile offenders, foster care adolescents, and normal adolescents [control group] $), F(8,890)=5.63, p<.001$, $1-\beta=1.0$, explaining $4.8 \%$ of the variance, $\eta_{\mathrm{p}}^{2}=.048$, and an effect larger than $62.55 \%\left(\mathrm{PS}_{\mathrm{ES}}=.6255\right)$ of all possible.

The univariate effects (see Table 1) showed significant differences between groups in personal, social, and family maladjustment. Post hoc comparisons (Bonferroni correction: $.05 / 3=.017)$ revealed higher personal maladjustment in foster care adolescents than in juvenile offenders and normal adolescents; juvenile offenders and foster care adolescents informed of more family maladjustment than normal adolescents; and juvenile offenders reported more social maladjustment than normal adolescents. Personal maladjustment was highest in 15\% $(r=.15)$ and 19\% $(r=.19)$ in foster care adolescents in comparison to juvenile offenders and normal adolescents; family maladjustment in foster care adolescents and juvenile offenders was $27 \%(r=.27)$ and $22 \%(r=.22)$ above normal adolescents; social maladjustment in juvenile offenders was $17 \%(r=.15)$ above normal adolescents.

The magnitude of the significant differences between populations $\left(\mathrm{PS}_{\mathrm{ES}}\right.$ in Table 1) was an effect size larger than 1/6 (.1742, juvenile offenders and foster care adolescents in personal maladjustment), $1 / 5$ (.1974, .2128, in social maladjustment between juvenile offenders and normal adolescents, and in personal maladjustment between adolescents in foster care and normal adolescents, respectively), 1/4 (.2586, in family maladjustment between juvenile offenders and normal adolescents), and 1/3 (.3108, in family maladjustment between foster care and normal adolescents) of all the possible effects with increased maladjustment. 
Table 1. Univariate effects in the individual adjustment for the population factor.

\begin{tabular}{lcccccccc}
\hline Variable & $F$ & $1-\beta$ & $M_{\mathrm{NA}}$ & $M_{\mathrm{FCA}}$ & $M_{\mathrm{JO}}$ & $d_{1}\left(\mathrm{PS}_{\mathrm{ES}}\right)$ & $d_{2}\left(\mathrm{PS}_{\mathrm{ES}}\right)$ \\
\hline Personal & $6.54^{* *}$ & .908 & 9.99 & 12.60 & 10.73 & $0.12(.5319)$ & $0.38(.2128)$ & $0.31(.1742)$ \\
School & 1.76 & .369 & 11.31 & 11.54 & 12.69 & $0.20(.5557)$ & $0.04(.5120)$ & $0.17(.5478)$ \\
Family & $13.65^{* * *}$ & .998 & 1.20 & 2.02 & 1.83 & $0.46(.2586)$ & $0.57(.3108)$ & $0.13(.5359)$ \\
Social & $5.06^{* *}$ & .818 & 10.70 & 12.03 & 12.53 & $0.36(.1974)$ & $0.25(.5714)$ & $0.10(.5279)$ \\
\hline
\end{tabular}

Note. $d f(2,447) ; M_{\mathrm{NA}}$ : mean of the normal adolescents (control group); $M_{\mathrm{FCA}}$ : mean of the group of foster care adolescents; $M_{\mathrm{JO}}$ : mean of the group of juvenile offenders; $d_{1}(\mathrm{PS} \mathrm{ES})$ : Cohen's $d$ for juvenile offenders vs. normal adolescents(Probability of Superiority of the Effect Size); $d_{2}\left(\mathrm{PS} \mathrm{Es}_{\mathrm{ES}}\right)$ : Cohen's $d$ for foster care adolescents vs. normal adolescents(Probability of Superiority of the Effect Size); $d_{3}\left(\mathrm{PS}_{\mathrm{ES}}\right)$ : Cohen's $d$ for juvenile offenders vs. foster care adolescents (Probability of Superiority of the Effect Size); ${ }^{* *} p<.01 ; * * p<.001$.

\section{Social adjustment}

The results of the MANOVA for social adjustment showed a significant multivariate effect for the population factor (juvenile offenders, foster care adolescents, and normal adolescents), $F(10,888)=12.38, p<.001,1-\beta=1.0$, explaining $12.2 \%$ of the variance, $\eta_{\mathrm{p}}{ }^{2}=.122$, an effect larger than $77.34 \%\left(\mathrm{PS}_{\mathrm{ES}}=.7734\right)$ of all possible.

The univariate effects revealed significant differences between the three groups (juvenile offenders, foster care adolescents, and normal adolescents) on the dimensions of consideration for others, social withdrawal, anxiety-shyness, and leadership (see Table 2). Post hoc comparisons revealed juvenile offenders exhibited less consideration for others than normal adolescents; and adolescents in foster care and juvenile offenders showed more social withdrawal, social anxiety/shyness, and leadership than normal adolescents.

The lack of consideration of juvenile offenders increased
$15 \%(r=.15)$ versus normal adolescents, with increases of $29 \%(r=.29)$ and $26 \%(r=.26)$ in social withdrawal, $32 \%(r$ $=.32)$ and $37 \%(r=.37)$ in anxiety shyness, and $24 \%(r=$ $.24)$ and $15 \%(r=.15)$ in leadership for juvenile offenders and adolescents in foster care, respectively, as compared to normal adolescents.

The magnitude of the significant differences between populations ( $\mathrm{PS}_{\mathrm{ES}}$ in Table 2) was of an effect size larger than $1 / 6(.1664$, in consideration towards others and leadership between juvenile offenders and normal adolescents); $1 / 4$ (.2736 and .2886, in social withdrawal and leadership between foster care and normal adolescents); $1 / 3$ (.3328 and .3616 in social withdrawal and anxiety shyness between juvenile offenders and normal adolescents); and almost $1 / 2$ (.4246 in anxiety shyness between de foster care and normal adolescents) of all possible effects with increased maladjustment.

Table 2. Univariate effects in the social adjustment for the population factor.

\begin{tabular}{lcccccccc}
\hline Variable & $F$ & $1-\beta$ & $M_{\mathrm{NA}}$ & $M_{\mathrm{FCA}}$ & $M_{\mathrm{JO}}$ & $d_{1}\left(\mathrm{PS}_{\mathrm{ES}}\right)$ & $d_{2}\left(\mathrm{PS}_{\mathrm{ES}}\right)$ & $d_{3}\left(\mathrm{PS}_{\mathrm{ES}}\right)$ \\
\hline Consideration & $3.74^{*}$ & .683 & 10.04 & 9.64 & 9.11 & $0.30(.1664)$ & $0.15(.0876)$ & $0.18(.1034)$ \\
Self-control & 1.20 & .262 & 8.64 & 9.14 & 8.71 & $0.02(.0800)$ & $0.15(.0876)$ & $0.15(.0876)$ \\
Social withdrawal & $16.16^{* * *}$ & 1.00 & 2.72 & 4.17 & 4.37 & $0.61(.3328)$ & $0.53(.2886)$ & $0.07(.0398)$ \\
Social/shyness anxiety & $25.67^{* * *}$ & 1.00 & 3.55 & 5.79 & 5.47 & $0.67(.3616)$ & $0.79(.4246)$ & $0.10(.0558)$ \\
Leadership & $9.22^{* * *}$ & .977 & 6.25 & 7.59 & 7.11 & $0.30(.16640$ & $0.49(.2736)$ & $0.18(.1034)$ \\
\hline
\end{tabular}

Note. $d f(2,447) ; M_{\mathrm{NA}}$ : mean of the normal adolescents (control group); $M_{\mathrm{FCA}}$ : mean of the group of foster care adolescents; $M_{\mathrm{J} O}$ : mean of the group of juvenile offenders; $d_{1}\left(\mathrm{PS} S_{\mathrm{ES})}\right.$ : Cohen's $d$ for juvenile offenders vs. normal adolescents(Probability of Superiority of the Effect Size); $d_{2}\left(\mathrm{PS}_{\mathrm{ES}}\right)$ : Cohen's $d$ for foster care adolescents vs. normal adolescents(Probability of Superiority of the Effect Size); $d_{3}\left(\mathrm{PS}_{\mathrm{Es}}\right)$ : Cohen's $d$ for juvenile offenders vs. foster care adolescents (Probability of Superiority of the Effect Size); ${ }^{*} p<.05 ; * * p<.001$.

\section{Psychological adjustment}

The MANOVA found a significant multivariate effect for the population factor (juvenile offenders, foster care adolescents, and normal adolescents), $F(18,880)=3.94, p<$ $.001,1-\beta=1.0$, in psychological adjustment explaining $7.5 \%$ of the variance, $\eta_{\mathrm{p}}{ }^{2}=.075$, an effect greater than $66.54 \%$ $\left(\mathrm{PS}_{\mathrm{ES}}=.6654\right)$ of all possible effects.

The univariate effects (see Table 3) showed significant differences in the 9 symptomatic dimensions by the population factor. The post hoc comparisons exhibited adolescents in foster care informed of more somatic, obsessivecompulsive, interpersonal sensitivity, depression, anxiety (generalized), hostile, phobic-anxiety, paranoid and psychotic symptomology than normal adolescents. In comparison, juvenile offenders reported more obsessive-compulsive, interpersonal sensitivity, depression, hostility, phobic-anxiety and psychotic symptoms. Finally, adolescents in foster care reported more somatic symptoms, anxiety (generalized), phobic-anxiety, and paranoid ideation than juvenile offenders.

The increase in the psychological maladjustment of adolescents in foster care compared to normal adolescents was $30 \%(r=.30)$ in somatization, $22 \%(r=.22)$ in obsessivecompulsive, 29\% $(r=.29)$ in depression, $24 \%(r=.24)$ in anxiety, $28 \%(r=.28)$ in hostility, $30 \%(r=.30)$ in phobicanxiety, $32 \%(r=.32)$ in paranoids ideation, and $24 \%(r=$ .24) in psychoticism. In comparison, the psychological maladjustment in juvenile offenders was higher than in normal adolescents by $17 \%(r=.17)$ in obsessive-compulsive, $20 \%$ $(r=.20)$ in depression, 24\% $(r=.24)$ in hostility, 19\% $(r=$ $.19)$ in phobic-anxiety, $21 \%(r=.21)$ in interpersonal sensitivity, and $17 \%(r=.17)$ in psychoticism. Finally, psychological harm in adolescents in foster care was higher than in juvenile offenders by $18 \%$ in somatic symptoms, $17 \%(r=.17)$ 
in anxiety (generalized), 14\% $(r=.14)$ in phobic-anxiety, and $21 \%$ in paranoid ideation.

The magnitude of the significant differences between populations ( $\mathrm{PS}_{\mathrm{ES}}$ in Table 3) was of an effect size larger than $1 / 6$ (.1586 in phobic-anxiety between juvenile offenders and adolescents in foster care); $1 / 5$ (.1896, .2202, and .1896 , in obsessive-compulsive, phobic-anxiety, and psychoticism between juvenile offenders and normal adolescents; .2040 and .1974 in somatization and anxiety between juvenile offenders and adolescents in foster care); 1/4 (.2282, .2736 and .2358 in depression, hostility, and interpersonal sensitivi- ty between juvenile offenders and normal adolescents; .2510, .2736 , and .2736 in obsessive-compulsive, anxiety, and psychoticism between foster care and normal adolescents; and .2358 in paranoid ideation between juvenile offenders and adolescents in foster care); and $1 / 3(.3400, .3328, .3182$, $.3400, .3616$, and .3526 in somatization, depression, hostility, phobic-anxiety, paranoid ideation, and interpersonal sensitivity, respectively, between de foster care and normal adolescents) of all possible incremental effects in psychological maladjustment.

Table 3. Univariate effects in the psychological adjustment for the population factor.

\begin{tabular}{|c|c|c|c|c|c|c|c|c|}
\hline Variable & $F$ & $1-\beta$ & $M_{\mathrm{NA}}$ & $M_{\mathrm{FCA}}$ & $M_{\mathrm{JO}}$ & $d_{1}\left(\mathrm{PS}_{\mathrm{ES}}\right)$ & $d_{2}\left(\mathrm{PS}_{\mathrm{ES}}\right)$ & $d_{3}\left(\mathrm{PS}_{\mathrm{ES}}\right)$ \\
\hline Somatization & $14.84 * * *$ & .999 & 5.42 & 9.10 & 6.91 & $0.30(.1664)$ & $0.62(.3400)$ & $0.37(.2040)$ \\
\hline Obsessive-compulsive & $8.39 * * *$ & .964 & 6.87 & 9.44 & 8.71 & $0.34(.1896)$ & $0.45(.2510)$ & $0.13(.0718)$ \\
\hline Interpersonal Sensitivity & $15.10^{* * *}$ & .999 & 3.55 & 5.95 & 5.09 & $0.42(.2358)$ & $0.63(.3526)$ & $0.22(.1272)$ \\
\hline Depression & $14.63^{* * *}$ & .999 & 3.56 & 5.93 & 5.09 & $0.41(.2282)$ & $0.61(.3328)$ & $0.21(.1192)$ \\
\hline Anxiety & $10.09 * * *$ & .985 & 6.64 & 9.33 & 7.33 & $0.14(.0796)$ & $0.49(.2736)$ & $0.35(.1974)$ \\
\hline Hostility & $14.32 * * *$ & .999 & 5.20 & 7.99 & 7.47 & $0.50(.2736)$ & $0.58(.3182)$ & $0.11(.0638)$ \\
\hline Phobic anxiety & $15.54 * * *$ & .999 & 4.38 & 7.18 & 5.85 & $0.39(.2202)$ & $0.62(.3400)$ & $0.28(.1586)$ \\
\hline Paranoid ideation & $18.75^{* * *}$ & 1.00 & 3.01 & 5.54 & 3.93 & $0.28(.1586)$ & $0.67(.3616)$ & $0.43(.2358)$ \\
\hline Psychoticism & $9.52^{* * *}$ & .980 & 4.73 & 7.07 & 6.27 & $0.34(.1896)$ & $0.49(.2736)$ & $0.17(.0956)$ \\
\hline
\end{tabular}

Note. $d f(2,447) ; M_{\mathrm{NA}}$ : mean of the normal adolescents (control group); $M_{\mathrm{FCA}}$ : mean of the group of foster care adolescents; $M_{\mathrm{jO}}$ : mean of the group of juvenile offenders; $d_{1}$ (PSEs): Cohen's $d$ for juvenile offenders vs. normal adolescents(Probability of Superiority of the Effect Size); $d_{2}(\mathrm{PS}$ Es): Cohen's $d$ for foster care adolescents vs. normal adolescents(Probability of Superiority of the Effect Size); $d_{3}\left(\mathrm{PS}_{\mathrm{ES}}\right)$ : Cohen's $d$ for juvenile offenders vs. foster care adolescents (Probability of Superiority of the Effect Size); ${ }^{* * *} p<.001$.

A MANOVA was performed revealing a significant multivariate effect on the global indexes of distress for the population factor (juvenile offenders, foster care adolescents, and normal adolescents), $F(6,892)=5.56, p<.001,1-\beta=.999$, explaining $3.6 \%$ of the variance, $\eta_{\mathrm{p}}{ }^{2}=.036$. The univariate effects (see Table 4) showed significant differences between populations in GSI, PST, and PSDI).

Table 4. Univariate effects in the global indices of distress for the population factor.

\begin{tabular}{lcccccccc}
\hline Index & $F$ & $1-\beta$ & $M_{\mathrm{NA}}$ & $M_{\mathrm{FCA}}$ & $M_{\mathrm{JO}}$ & $d_{1}\left(\mathrm{PS}_{\mathrm{ES}}\right)$ & $d_{2}\left(\mathrm{PS}_{\mathrm{ES}}\right)$ & $0.64(.3472)$ \\
GSI & $16.42^{* * *}$ & .997 & 0.91 & 1.40 & 1.18 & $0.39(.2206)$ & $0.28(.1586)$ \\
PST & $10.45^{* * *}$ & .988 & 25.07 & 31.93 & 28.97 & $0.31(.1740)$ & $0.52(.2886)$ \\
PSDI & $8.30^{* * *}$ & .962 & .033 & .042 & .039 & $0.43(.2358)$ & $0.22(.1272)$ & $0.40(.2206)$ \\
\hline
\end{tabular}

Note. $d f(2,447) ; M_{\mathrm{NA}}$ : mean of the normal adolescents (control group); $M_{\mathrm{FCA}}$ : mean of the group of foster care adolescents; $M_{\mathrm{jO}}$ : mean of the group of juvenile offenders; $d_{1}\left(\mathrm{PS}_{\mathrm{ES}}\right)$ : Cohen's $d$ for juvenile offenders vs. normal adolescents(Probability of Superiority of the Effect Size); $d_{2}\left(\mathrm{PS} \mathrm{ES}_{\mathrm{ES}}\right)$ Cohen's $d$ for foster care adolescents vs. normal adolescents(Probability of Superiority of the Effect Size); $d_{3}\left(\mathrm{PS}_{\mathrm{Es}}\right)$ : Cohen's $d$ for juvenile offenders vs. foster care adolescents (Probability of Superiority of the Effect Size); ${ }^{* * *} p<.001$.

Post hoc comparisons showed juvenile offenders and foster care adolescents reported a higher GSI (global severity), PST (positive symptom total) and PSDI (positive symptom distress) than normal adolescents; and adolescents in foster care reported a higher GSI than juvenile offenders.

The increases in GSI, PST, and PSDI in juvenile offenders as compared to normal adolescents were $19 \%, 15 \%$, and $21 \%\left(r_{\mathrm{s}}=.30, .25\right.$ and .20$)$, respectively. In contrast, adolescents in foster care informed of a 30,25 , and $20 \%$ higher GSI, PST, and PSDI than normal adolescents. Finally, global severity was $14 \%$ higher in adolescents in foster care than in juvenile offenders.

The magnitude of the significant differences between populations $\left(\mathrm{PS}_{\mathrm{ES}}\right.$ in Table 4) was of an effect size larger than 1/6 (.1586 in global severity between foster care adolescents and juvenile offenders; and .1740 between juvenile offenders and normal adolescents); $1 / 4$ (.2206 in the GSI between juvenile offenders and normal adolescents; and .2206 in the PSDI between foster care and normal adolescents); $1 / 5$ (.2358 in the PSDI between juvenile offenders and normal adolescents; and 2886 in the PST between foster care and normal adolescents); and 1/3 (.3472 in the GSI between foster care and normal adolescents) of all possible effects with an increase in maladjustment.

\section{Discussion}

The results of the present study are subject to several limitations concerning generalizations. First the experimental design of the study was based on the assumption that the participants' responses were honest, but a systematic error should always be suspected with juvenile offenders due to 
malingering/lying (American Psychiatric Association [APA], 2013)or the feigning of positive characteristics or to concealing adverse symptomology (Fariña et al., 2017). Second, the design assumed a direct and accumulative effect of the measurement variables of delinquency, but other relations are possible. Third, besides risk, protective, and promotive variables, other variables may mediate or moderate effects on delinquent behaviour. Fourth, the research context of Colombian adolescents restricts the generalization of the results to other contexts. Fifth, the objective of the design was to define risk factors, but these cannot be generalized to other conditions such as mixed or promotive factors. Sixth, the needs identified in risk adolescents are characteristic of the specific population at risk in this study (adolescents in foster care), and these needs may not overlap with the needs of other risk populations (e.g., adolescents from risk neighbourhoods/communities). Bearing these limitations in mind, from the results of this study the following conclusions may be drawn:

a) Concerning individual adjustment. The population factor explained around $5 \%$ of individual (mal)adjustment. Indeed, juvenile offenders and adolescents in foster care showed deficits in family adjustment (i.e., negative family atmosphere and parental disputes); adolescents in foster care showed deficits in personal (mal)adjustment (i.e., personal dissatisfaction and affective maladjustment); and juvenile offenders in social (mal)adjustment (i.e., social aggressiveness, violating norms, few social relations, and social mistrust). This maladjustment is estimated to diminish approximately 20 to $30 \%$ the individual skills, and in terms of the magnitude of the negative effect, it was greater than between $1 / 5$ and $1 / 3$ of all possible effects, that is, harm was not only significant, but also extensive and serious. The findings in the family, personal, and social maladjustment of juvenile offenders and high risk adolescents are accumulative to problems in other areas of individual functioning: greater vulnerability to physical illness (Martinón et al., 2017); low academic performance and school absenteeism and dropouts (Corrás et al., 2017); increased probability of witnessing and/or experiencing intimate partner and family violence (Seijo, Fariña, Corrás, Novo, \& Arce, 2016), or being a victim of child-to-parent violence (Loinaz \& de Sousa, 2020); and of an authoritarian style of parenting associated to the use of violence and delinquent behaviour (RuizHernández, Moral-Zafra, Llor-Esteban, \& JiménezBarbero, 2019). In short, individual maladjustment is not only associated to delinquency and the risk of delinquency, but also to maladjustment in other areas of individual functioning (APA, 2013). Thus, both delinquency prevention and intervention programs should seek the rehabilitation of individual adjustment, and strive to repair extensive and serious harm.

b) Concerning social adjustment. The population explained around $12 \%$ of social (mal)adjustment. Thus, juvenile offenders and adolescents in foster showed social seclusion (i.e., active and passive isolation from others), anxiety social/shyness (i.e., expressing fear and shyness in social relations), and leadership (i.e., excess of ascendancy, popularity, initiative, and self-confidence); and juvenile offenders showed in consideration for others (i.e., scarce social sensitivity or consideration for others). Succinctly, deficiencies in socialization facilitate associations to deviant peer affiliations (risk factor), and control the cognitive barrier inhibiting delinquent behaviour (inhibits an interactive protective factor) (Arce et al., 2010; Cutrín et al., 2019; Férriz, Sobral, \& Goméz-Fraguela, 2018). These deviations of normality reached between 15 to close to $40 \%$, and in terms of the magnitude of the negative effect, it was larger than $1 / 6$ to $1 / 2$ of all possible effects, that is, deterioration in social adjustment was extensive and deep. These deviations in the normality of social adjustment (socialization) precede delinquent behaviour, particularly applicable to adolescents at risk (Novo et al., 2012), and are linked to the persistency in delinquent behaviours i.e., multi-recidivism, especially among juvenile offenders (Maruna, 2004). Thus, both prevention and intervention programs should target needs associated to the individual's social maladjustment with substantial effects given that harm is considerably acute.

c) Concerning psychological adjustment. The population explained around $7.5 \%$ of psychological (mal)adjustment. Thus, juvenile offenders and adolescents in foster care showed more symptomology than normal adolescents in obsessive-compulsive (thoughts, impulses and actions that are experienced as unremitting and irresistible by the individual being of an ego-alyen or unwanted nature), interpersonal sensitivity (feelings of personal inadequacy and inferiority, self-deprecation, feelings of uneasiness, and marked discomfort in interpersonal interactions), depression (signs of withdrawal of life interest, lack of motivation, and loss of vital energy), hostility (thoughts, feelings or actions that are characteristics of negative affect state of anger, aggression, irritability, ty, rage, anger and resentment), phobic-anxiety (persistent fear response to a specific person, place, object or situation, that is characterized as being irrational and disproportionate leaving to avoidance or scape behaviors) and psychoticism (in nonclinical populations: mistrust/cynicism, withdraw, and living in a fantasy life). Additionally, adolescents in foster care reported more somatic (distress arising from perceptions of bodily dysfunctions), anxiety (nervousness, tension, feelings of terror, apprehension and dread), and paranoid ideation (i.e., aggression, anger, fury, irritability, rage, resentment, suspicious, fear of losing autonomy, need of control) symptoms than normal adolescents. Moreover, juvenile offenders and adolescents in foster care informed of more global severity, more positive symptoms, and more distress referring to positive symptoms. These deviations to normality ranged from 17 to $32 \%$, and in terms of the magnitude of the negative ef- 
fect, it was larger than from $1 / 6$ to $1 / 3$ of all possible effects, that is, deterioration in psychological adjustment was from moderate to severe (Endicott, Spitzer, Fleiss, \& Cohen 1976). The association between internalizing problems (e.g., depression, anxiety, paranoid ideation) and externalizing ones (e.g., hostility, aggression) has been corroborated by previous studies in diverse criminal contexts (Arce et al., 2011; Baskin-Sommers et al., 2016; Carswell, Maughan, Davis, Davenport, \& Goddard, 2004; Novo et al., 2012), as well as its role in the development of adult delinquency (Basto-Pereira \& Maia, 2017). Similar to the findings of present study, psychological instability was also found to be a characteristic of adolescents in foster care ((Bastiaanssen, Delsing, Kroes, Engels, \& Veerman, 2014). Moreover, deficiencies in these health markers have been found to be vehicles of recidivism (Basanta et al., 2018; Fariña et al., 2014; Novo et al., 2012). However, the magnitude of harm and its effect on mental health markers remains unclear. Thus, the priority of delinquency prevention and intervention programs should be to promote psychological reequilibrium, bearing in mind the magnitude of harm ranged from moderate to severe, the magnitude of the intervention should also be large.

\section{References}

Álvarez-García, D., Núñez, J. C., García, T., \& Barreiro-Collazo, A. (2018). Individual, family, and community predictors of cyber-aggression among adolescents. European Journal of Psycbology Applied to Legal Context, 10(2), 79-88. https://doi.org/10.5093/ejpalc2018a8

American Psychiatric Association. (2013). Diagnostic and statistical manual of mental disorders (5th ed.). Washington, DC: Author.

Aragón, N., Bragado, M. C., \& Carrasco, I. (2000). Fiabilidad y estructura factorial del «Inventario Breve de Síntomas» (Brief Symptom Inventory, BSI) en adultos. [Reliability and factor structure of the "Brief Symptom Inventory (BSI) in adults], Psicología Conductual, 8, 73-83.

Arce, R., Arias, E., Novo, M. \& Fariña, F. (2020). Are interventions with batterer effective? A meta-analytical review. Psychosocial Intervention. Advance online publication. https://doi.org/10.5093/pi2020a11

Arce, R., Fariña, F., \& Fraga, A. (2000). Género y formación de juicios en un caso de violación [Gender and juror judgment making in a case of rape]. Psicothema, 12(4), 623-628. Retrieved from http://www.psicothema.com/pdf/381.pdf

Arce, R., Fariña, F., \& Novo, M. (2014). Competencia cognitiva en penados primarios y reincidentes: Implicaciones para la reeducación [Cognitive competence among recidivist and non-recidivist prisoners: Implications for the rehabilitation]. Anales de Psicologia, 30(1), 259-266. http://dx.doi.org/10.6018/analesps.30.1.158201

Arce, R., Fariña, F., \& Vázquez, M. J. (2011). Grado de competencia social y comportamientos antisociales delictivos y no delictivos en menores [Social competence and delinquent, antisocial, and non-deviant behavior in adolescents]. Revista Latinoamericana de Psicologia, 43(3), 473-486. http://dx.doi.org/10.14349/rlp.v43i3.487

Arce, R., Seijo, D., Fariña, F., \& Mohamed-Mohand, L. (2010). Comportamiento antisocial en menores: Riesgo social y trayectoria natural de desarrollo [Antisocial behavior in adolescents: Social risk and natural developmental trajectory]. Revista Mexicana de Psicologia, 27(2), 127-142. Retrieved from https://www.redalyc.org/pdf/2430/243016324002.pdf

Basanta, J., Fariña, F., \& Arce, R. (2018). Risk-Need-Responsivity Model: Contrasting criminogenic and noncriminogenic needs in high and low risk juvenile offenders. Children and Youth Services Review, 85, 137-142. https://doi.org/10.1016/j.childyouth.2017.12.024 d) Concerning needs in situations of risk. Additionally, adolescents in foster care (risk) presented more individual maladjustment (deficits in personal adjustment), more clinical symptomology (somatic, generalized and specific anxiety, and paranoid ideation), and more global clinical severitythan juvenile offenders. Succinctly, adolescents at risk were not only as deficient in normality as juvenile offenders, but were even more so than juvenile offenders. Thus the risk of becoming a delinquent is heightened, as is the need for prevention intervention programs design to address all of these needs in order to thwart the onset of delinquency among at risk adolescents (Arce et al., 2010).

In short, the content of intervention programs should be tailored to address the specific needs of adolescents (Bonta \& Andrews, 2017) through efficacious intervention techniques (Novo et al., 2019; Van der Stouwe et al., 2020), targeting both the criminogenic needs and non-criminogenic personal, social, and psychological needs of juvenile offenders and at risk adolescents.

Funding: This research has been sponsored by a grant of the Spanish Ministry of Economy, Industry and Competitiveness (PSI2017-87278-R).

Baskin-Sommers, A. R., Baskin, D. R., Sommers, I., Casados, A. T., Crossman, M. K., \& Javdani, S. (2016). The impact of psychopathology, race, and environmental context on violent offending in a male adolescent sample. Personality Disorders: Theory, Research, and Treatment, 7(4), 354-362. https://doi.org/10.1037/per0000168

Bastiaanssen, I. L., Delsing, M. J., Kroes, G., Engels, R. C., \& Veerman, J. W. (2014). Group care worker interventions and child problem behavior in residential youth care: Course and bidirectional associations. Children and Youth Services Review, 39, 48-56.

Basto-Pereira, M., \& Maia, A. C. (2019). Early adversity and adult delinquency: The mediational role of mental health in youth offenders. Ciencia \& Saude Coletiva, 24, 2805-2810. http://dx.doi.org10.1590/141381232018248.27142017

Bonta, J., \& Andrews, D. A. (2017). The psychology of criminal conduct (6th ed.). New York, NY: Routledge.

Carswell, K., Maughan, B., Davis, H., Davenport, F., \& Goddard, N. (2004). The psychosocial needs of young offenders and adolescents from an inner city area. Journal of Adolescence, 27, 415-428. https://doi.org/10.1016/j.adolescence.2004.04.003

Corrás, T., Seijo, D., Fariña, F., Novo, M., Arce, R., \& Cabanach, R. G. (2017). What and how much do children lose in academic settings owing to parental separation? Frontiers in Psychology, 8, 1545 http://doi.org/10.3389/fpsyg.2017.01545

Cutrín, O., Maneiro, L., Sobral, J., \& Gómez-Fraguela, J. A. (2019). Longitudinal effects of parenting mediated by deviant peers on violent and non-violent antisocial behaviour and substance use in adolescence. Eu ropean Journal of Psychology Applied to Legal Context, 11(1), 23-32. https://doi.org/10.5093/ejpalc2018a12

Endicott, J., Spitzer, R. L., Fleiss, J. L., \& Cohen, J. (1976). The Global Assessment Scale: A procedure for measuring overall severity of psychiatric disturbance. Archives of General Psychiatry, 33(6), 766-771. https://doi.org/10.1001/archpsyc.1976.01770060086012

Fariña, F., Arce, R., \& Novo, M. (2008). Neighborhood and community factors: Effects on deviant behavior and social competence. Spanish Journal of Psychology, 11(1), 78-84. http://dx.doi.org/10.1017/S1138741600004133 
Fariña, F., Arce, R., \& Vázquez, M. J. (2014). ¿Está mediada la gravedad delictiva y cronicidad de los delincuentes juveniles por la competencia cognitivo-comportamental? [Is offence severity and the chronicity of juvenile delinquency mediated by cognitive-behavioural competence?]. Universitas Psychologica, 13(3), 15-27. http://dx.doi.org/10.11144/Javeriana.UPSY13-3.emgd

Fariña, F., Redondo, L., Seijo, D., Novo, M., \& Arce, R. (2017). A metaanalytic review of the MMPI validity scales and indexes to detect defensiveness in custody evaluations. International Journal of Clinical and Health Psychology, 17, 128-138. http://dx.doi.org/10.1016/j.ijchp.2017.02.002

Farrington, D. P., Gaffney, H., \& Ttofi, M. M. (2017). Systematic reviews of explanatory risk factors for violence, offending, and delinquency. $A g$ gression and Violent Behavior, 33, 24-36. https://doi.org/10.1016/j.avb.2016.11.004

Farrington, D. P., Ttofi, M. M., \& Piquero, A. R. (2016). Risk, promotive, and protective factors in youth offending: Results from the Cambridge study in delinquent development. Journal of Criminal Justice, 45, 63-70. https://doi.org/10.1016/i.jcrimjus.2016.02.014

Férriz, L., Sobral, J., \& Gómez-Fraguela, J. A. (2018). Empatía y delincuencia juvenil: Un meta-análisis sobre la relación [Empathy and juvenile delinquency: A meta-analytic review]. Revista Iberoamericana de Psicología y Salud, 9(1), 1-16. https://doi.org/10.23923/j.rips.2018.01.011

Hoeve, M., Dubas, J. S., Eichelsheim, V. I., Van der Laan, P. H., Smeenk, W., \& Gerris, J. R. (2009). The relationship between parenting and delinquency: A meta-analysis. Journal of Abnormal Child Psychology, 37(6), 749-775. https://dx.doi.org/10.1007\%2Fs10802-009-9310-8

Hutchings, J. N., Gannon, T. A., \& Gilchrist, E. (2010). A preliminary investigation of a new pictorial method of measuring aggressionsupportive cognition among young aggressive males. International Journal of Offender Therapy and Comparative Criminology, 54(2), 236-249. https://doi.org/10.1177/0306624X08325350

Loeber, R., Slot, N. W., \& Stouthamer-Loeber, M. (2008). A cumulative developmental model of risk and promotive factors. In R. Loeber, H. M. Koot, N. W. Slot, P. H. Van der Laan \& M. Hoeve (Eds.), Tomorrow's criminals: The development of child delinquency and effective interventions. Hampshire, UK: Ashgate.

Loinaz, I., \& de Sousa, A. M. (2020). La evaluación de factores de riesgo y de protección en casos clínicos y judiciales de violencia filio-parental. [Assessment of risk and protective factors in clinical and judicial cases of child-parent violence]. European Journal of Psychology Applied to Legal Context, 12, 43-51. https://doi.org/10.5093/ejpalc2020a5

Lösel, F., Kolip, P., \& Bender, D. (1992). Stress-resistance in a multiproblem milieu: Are resilient juveniles 'Superkids'. Zeitschrift für Klinische Psychologie, 21, 48-63

Marshall, N. A., Arnold, D. H., Rolon-Arroyo, B., \& Griffith, S. F. (2015). The association between relational aggression and internalizing symptoms: A review and meta-analysis. Journal of Social and Clinical Psychology, 34, 135-160. http://dx.doi.org/10.1521/jscp.2015.34.2.135

Martinón, J. M., Fariña, F., Corras, T., Seijo, D., Souto, A., \& Novo, M. (2017). Impacto de la ruptura de los progenitores en el estado de salud física de los hijos. [Impact of the breakdown of the parents on the physical health of the children]. European Journal of Education and Psychology, 10(1), 9-14. https://doi.org/10.1016/j.ejeps.2016.10.002

Maruna, S. (2004). Desistance and explanatory style: A new direction in the psychology of reform. Journal of Contemporary Criminal Justice, 20, 184200. https://doi.org/10.1177/1043986204263778
McGuire, J. (2000). Explanations of criminal behavior. In J. McGuire, T. Mason \& A. O' Kane (Eds.). Behavior, crime and legal processes: A guide for forensic practitioners (pp. 135-159). Chichester, UK: John Wiley and Sons.

Monteiro, A., Vázquez, M. J., Seijo, D., \& Arce, R. (2018). ¿Son los criterios de realidad válidos para clasificar y discernir entre memorias de hechos auto-experimentados y de eventos vistos en vídeo? [Are the reality criteria valid to classify and to discriminate between memories of selfexperienced events and memories of video-observed events?] Revista Iberoamericana de Psicología y Salud, 9(2), 149-160. https://doi.org/10.23923/j.rips.2018.02.020

Novo, M., Fariña, F., Seijo, D., \& Arce, R. (2012). Assessment of a community rehabilitation programme in convicted male intimate-partner violent offenders. International Journal of Clinical and Health Psychology, 12(2), 219-234. Retrieved from http://www.aepc.es/ijchp/articulos_pdf/ijchp-408.pdf

Novo, M., Fariña, F., Seijo, D., Vázquez, M. J., \& Arce, R. (2019). Assessing the effects of a parental separation education program on mental health problems. Psicothema, 31(3), 284-291. https://doi.org/10.7334/psicothema2018.299

Olson, C. L. (1976). On choosing a test statistic in Manova. Psychological Bulletin, 83, 579-586. https://psycnet.apa.org/doi/10.1037/00332909.83.4.579

Redondo, L., Fariña, F., Seijo, D., Novo, M., \& Arce, R. (2019). A metaanalytical review of the responses in the MMPI-2/MMPI-2-RF clinical and restructured scales of parents in child custody dispute. Anales de Psicología, 35(1) 156-165. http://dx.doi.org/10.6018/analesps.35.1.338381

Ruiz-Hernández, J. A., Moral-Zafra, E., Llor-Esteban, B., \& JiménezBarbero, J. A. (2019). Influence of parental styles and other psychosocial variables on the development of externalizing behaviors in adolescents: A systematic review. European Journal of Psychology Applied to Legal Context, 11(1), 9-21. https://doi.org/10.5093/ejpalc2018a11

Seijo, D., Fariña, F., Corrás, T., Novo, M., \& Arce, R. (2016). Estimating the epidemiology and quantifying the damages of parental separation in children and adolescents. Frontiers in Psychology, 7, 1611. https://doi.org/10.3389/fpsyg.2016.01611

Silva, F. \& Martorell, C. (1989). BAS-3. Batería de socialización. Manual. [BAS3. Socialization battery. Handbook] Madrid: TEA.

Smokowski, P. R., Guo, S., Evans, C. B. R., Wu, Q., Rose, R. A., Bacallao, M., \& Cotter, K. L. (2017). Risk and protective factors across multiple microsystems associated with internalizing symptoms and aggressive behavior in rural adolescents: Modeling longitudinal trajectories from the rural adaptation project. American Journal of Orthopsychiatry, 87(1), 94108. https://psycnet.apa.org/doi/10.1037/ort0000163

Van der Stouwe, T., Gubbels, J., Castenmiller, Y. L., Van der Zouwen, M., Asscher, J. J., Hoeve, M., ... \& Stams, G. J. J. (2020). The effectiveness of social skills training (SST) for juvenile delinquents: A meta-analytical review. Journal of Experimental Criminology. Advance online publication. https://doi.org/10.1007/s11292-020-09419-w

Werner, E. E., \& Smith, R. S. (1992). Vulnerable but invencible. New York, NY: McGraw-Hill.

Wibbelink, C. J., Hoeve, M., Stams, G. J. J., \& Oort, F. J. (2017). A metaanalysis of the association between mental disorders and juvenile recidivism. Aggression and Violent Behavior, 33, 78-90. https://doi.org/10.1016/j.avb.2017.01.005 